\title{
ANALISA TEGANGAN KERUSAKAN PADA PIN HOPPER
}

\section{STRESS ANALYSIS OF FAILED ON PIN HOPPER}

\author{
M. N. Setia Nusa \\ Balai Besar Teknologi Kekuatan Struktur - BPP Teknologi \\ e-mail: setia_nusa@yahoo.com
}

\begin{abstract}
Abstrak
Hopper pada Stage Regenerator mengalami kerusakan berupa jatuh dan robek. Hal ini disebabkan karena lepasnya salah satu pin yang menjadi tumpuan hopper. Setelah diperiksa ternyata pin tersebut bengkok dan salah satu stoppernya lepas.Dilakukan penelitian dengan analisa tegangan menggunakan Finite Element Analysis (FEA) dengan menggunakan type elemen plat untuk memodelkan shell Hopper dan solid elemen untuk Pin. Analisa tegangan dilakukan pada model Hopper untuk menentukan beban yang bekerja pada Pin kemudian dilakukan FEA pin untuk menentukan tegangan yang terjadi pada pin. Hasil perhitungan: Rupture allowable stress/Sr untuk 100.000 jam operasi sebesar 3,2 ksi (2,24 kg/mm²). Karena tegangan yang terjadi pada pin disebabkan oleh bending maka tegangan yang terjadi harus lebih kecil dari 1,5 $\mathrm{Sr}=3,36$ $\mathrm{kg} / \mathrm{mm}^{2}$, jadi dari FEA distribusi tegangan Pin yang dipakai harus diameter 70 $\mathrm{mm}$.
\end{abstract}

Kata kunci : Hopper, Pin bengkok, Jatuh, FEA, Pin 70 mm.

\begin{abstract}
Hopper at the stage regenerator failed due to falling and break, after visual examination it is found that the pin is bent and a stopper goes out. It is then conducted stress analysis using Finite Element Analysis (FEA) by means of plate element mode to model the hopper cell and solid element of the pin stress analysis is conducted for modelling the hopper is to determine working load on the pin followed by FEA to determine stresses taking place on the pin the calculation result are: rupture allowable stress (SR) for 100.000 operation hours is $3.2 \mathrm{Ksi}$ $\left(2.24 \mathrm{~kg} / \mathrm{mm}^{2}\right)$. As stress on the pin is caused by bending, the stress should be lower than $1.5 \mathrm{SR}$ or $3.36 \mathrm{~kg} / \mathrm{mm}^{2}$, and from FEA stress distribution on the pin should use pin with $70 \mathrm{~mm}$ in diameter.
\end{abstract}

Keywords : Hopper, Bend, Fall, FEA, Pin $70 \mathrm{~mm}$

Diterima (received) : 14 Februari 2014, Direvisi (reviewed) : 18 Februari 2014,

Disetujui (accepted) : 2 Maret 2014

\section{PENDAHULUAN}

Alat atau peralatan yang berfungsi menampung katalis dan mendistribusikannya yang lebih dikenal dengan nama Hopper, dimana tumpuan dari hopper ini terdapat pin, pin tersebut yang menahan beban hopper mengalami kerusakan, robek, putus dan jatuh yang berlokasi pada Stage Regenerator. Hal ini disebabkan kerena lepasnya salah satu pin yang menjadi tumpuan hopper. Pin tersebut bengkok dan salah satu stopper lepas, dilakukan perhitungan dengan menggunakan finite element analysis. Barometer perhitungan beban yang akan mempengaruhi perhitungan stress analysis antara lain mmaterial yang digunakan, temperatur lingkungan saat beroperasi, tekanan atau beban yang diterima, beban bending, beban aliran material pada hopper/berat katalis, serta gaya yang bekerja pada pin. Perhitungan ini dilakukan untuk mengetahui kenapa kerusakan ini sampai terjadi dan untuk menghindari agar kerusakan ini tidak terjadi lagi pada masa yang akan datang. 
Dimensi dan data teknis dari Hopper dan pin diambil dari DWG. No. D-15-1351-009F-B sebagai berikut :
1. Material
: SS $304 \mathrm{H}$
2. Temperatur, $\mathrm{T}$
$: 750{ }^{\circ} \mathrm{C}$
3. Pressure, $\mathrm{p}$
$: 3.5 \mathrm{~kg} / \mathrm{mm}^{2} \mathrm{G}$
4. Massa jenis Katalis, $\rho: 0,8 \mathrm{Ton} / \mathrm{m}^{3}, 0,4$ $\mathrm{Ton} / \mathrm{m}^{3}$ (Fluidized)
5. Max. Flow : $3.762 .625 \mathrm{Kg} / \mathrm{HR}$

Dari data dan informasi tentang kerusakan yang terjadi pada Pin untuk beberapa tahun terakhir tidak sering terjadi baik berupa fatique maupun korosi apalagi sampai robek dan jatuh, sedangkan yang diteliti pada saat ini adalah kejadian kedua, dimana pada kerusakan pada material sebelumnya hanya ditemukan retak dan segera diketahui dan direvisi.

Untuk itu dilakukan penelitian dan perhitungan terhadap material tersebut, Dari hasil identifikasi, material tersebut sesuai dengan spesifikasinya.

\section{BAHAN DAN METODE}

Analisa tegangan dilakukan dengan menggunakan Finite Element Analysis (FEA) software MSC/Nastran dengan menggunakan type elemen plat untuk memodelkan shell Hopper dan solid elemen untuk Pin seperti ditunjukkan pada Gambar 1. Analisa tegangan pertama dilakukan pada model Hopper untuk menentukan beban yang bekerja pada Pin kemudian dilakukan FEA pin untuk menentukan tegangan yang terjadi pada pin. Perhitungan dilakukan untuk menentukan dimensi Pin.

Rupture allowable stress, $\mathrm{Sr}$, untuk 100.000 jam operasi pada temperature 750 ${ }^{\circ} \mathrm{C}$ adalah sebesar 3,2 ksi $\left(2,24 \mathrm{~kg} / \mathrm{mm}^{2}\right)$. Kerena tegangan yang terjadi pada pin disebabkan oleh bending maka tegangan yang terjadi harus lebih kecil dari 1,5 $\mathrm{Sr}=$ $3,36 \mathrm{~kg} / \mathrm{mm}^{2}$,

\section{HASIL DAN PEMBAHASAN}

FEA Hopper

Berdasarkan dimensi dari hopper pada DRW. No. D-15-1351-009F-B, model FEA Hopper adalah sebagai berikut :

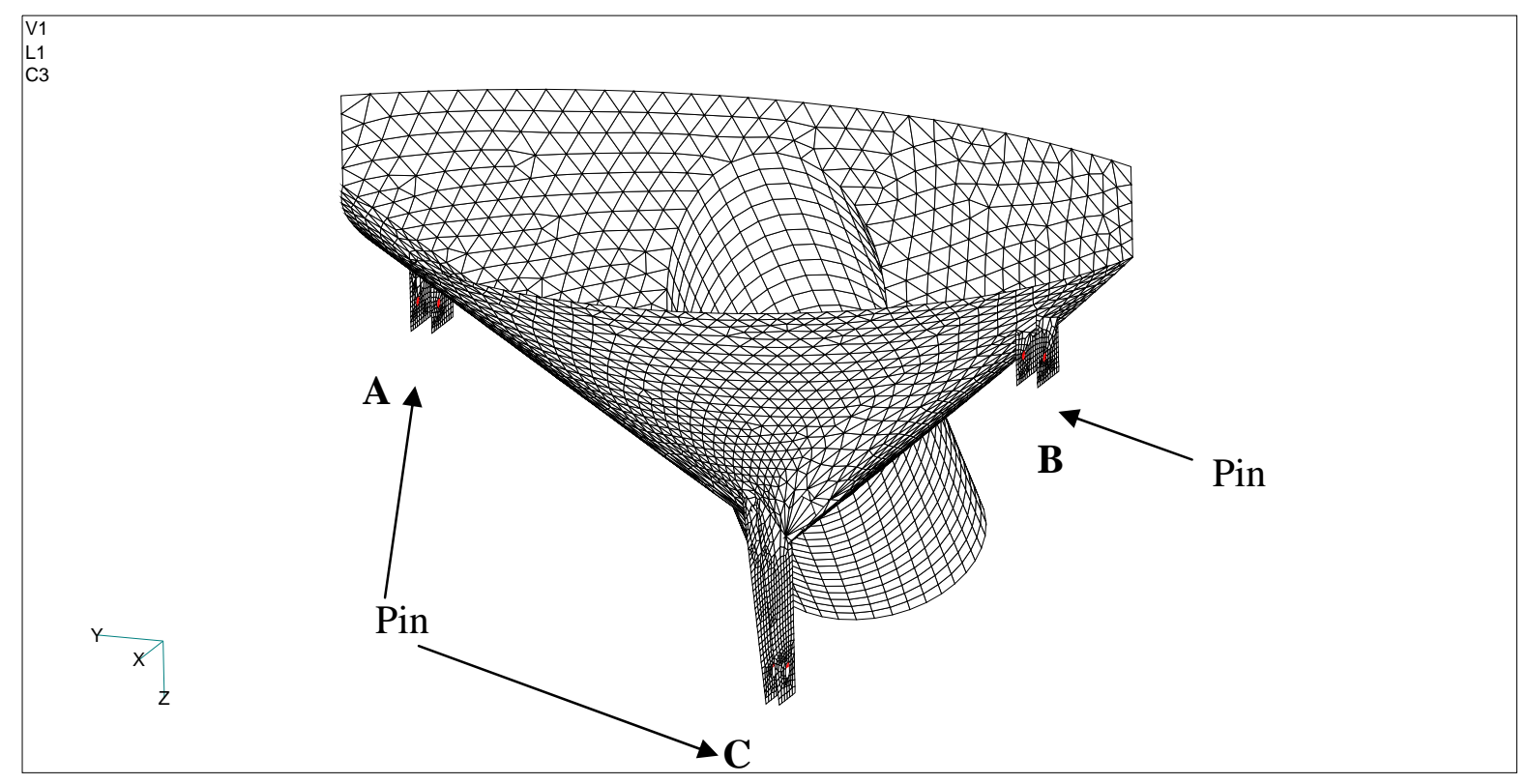

Gambar 1.

Model FEA Hopper 


\section{Pembebanan}

Perhitungan dilakukan dengan pembebanan berikut

1. Berat Katalis

Perhitungan ini mengasumsikan bahwa tidak ada aliran katalis pada Stand Pipe sehingga katalis terkumpul pada Hopper. Dalam hal ini hopper menerima pembebanan berupa berat total katalis. Dengan menghitung volume katalis sebesar $5 \mathrm{~m} 3(2 \times$ volume bagian kerucut hopper) dan berat jenis katalis 0,8 ton/m3 maka berat total katalis adalah sebesar $4.000 \mathrm{~kg}$.
2. Pressure Flow

Tekanan akibat aliran katalis dihitung sebagai berikut :

Flow rate maksimum katalis sebesar 3.762.625 Kg/HR memberikan kecepatan katalis melewati stand pipe sebesar $v=2,75 \mathrm{~m} /$ detik. Pressure akibat flow tersebut adalah:

$$
P=\rho \frac{v^{2}}{2}\left(\mathrm{~kg} / \mathrm{mm}^{2}\right)
$$

(1)

$$
P=1,5123 \mathrm{E}-6 \mathrm{~kg} / \mathrm{mm}^{2}
$$

Tekanan tersebut bekerja pada semua dinding hopper.

\section{Hasil Perhitungan FEA.}

Hasil perhitungan untuk kedua jenis pembebanan adalah sebagai berikut :

1. Berat Katalis

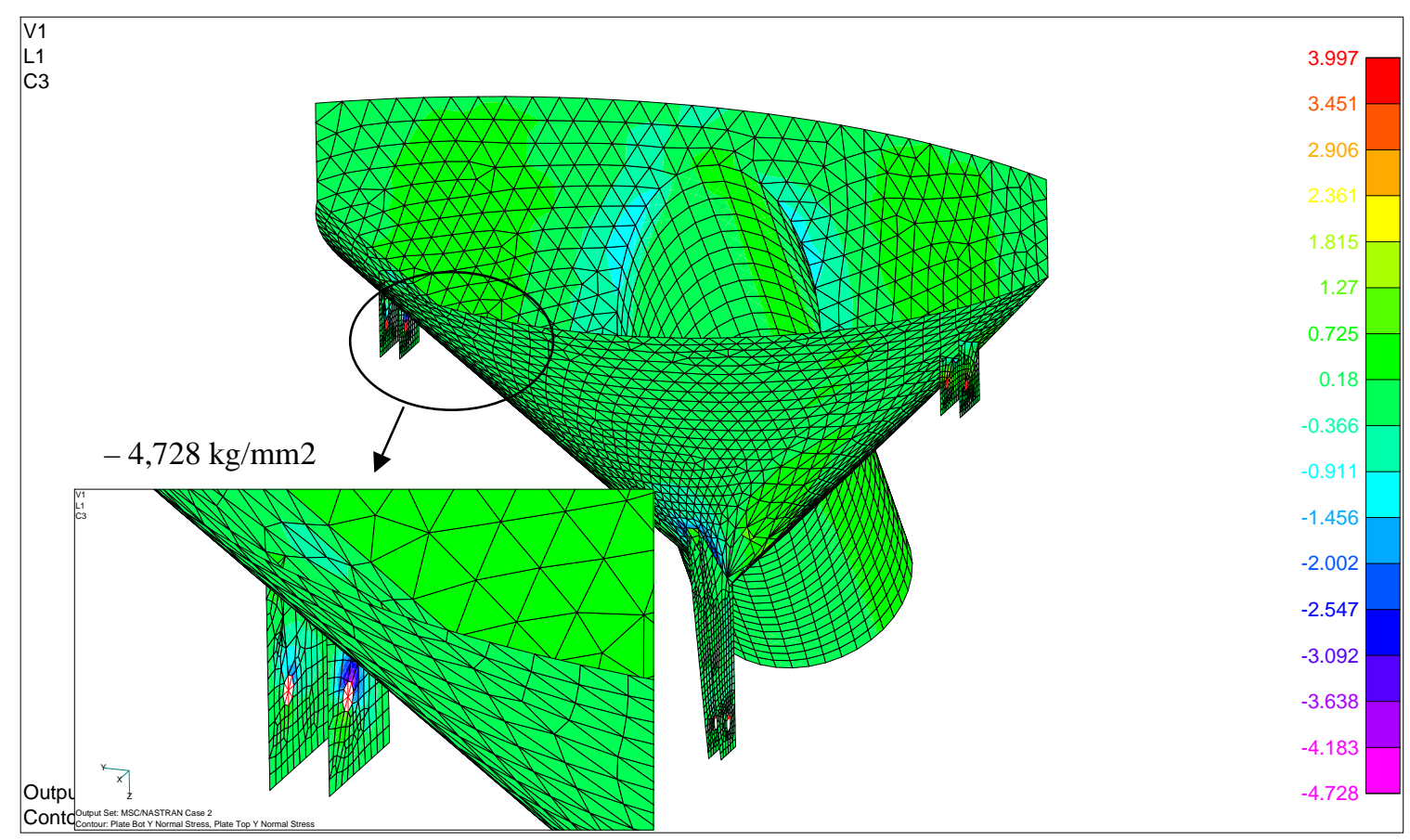

Gambar 2.

Distribusi Tegangan Pada Hopper, Tegangan Pada Daerah Pin - 4,728 kg/mm² 


\section{Pressure Flow}

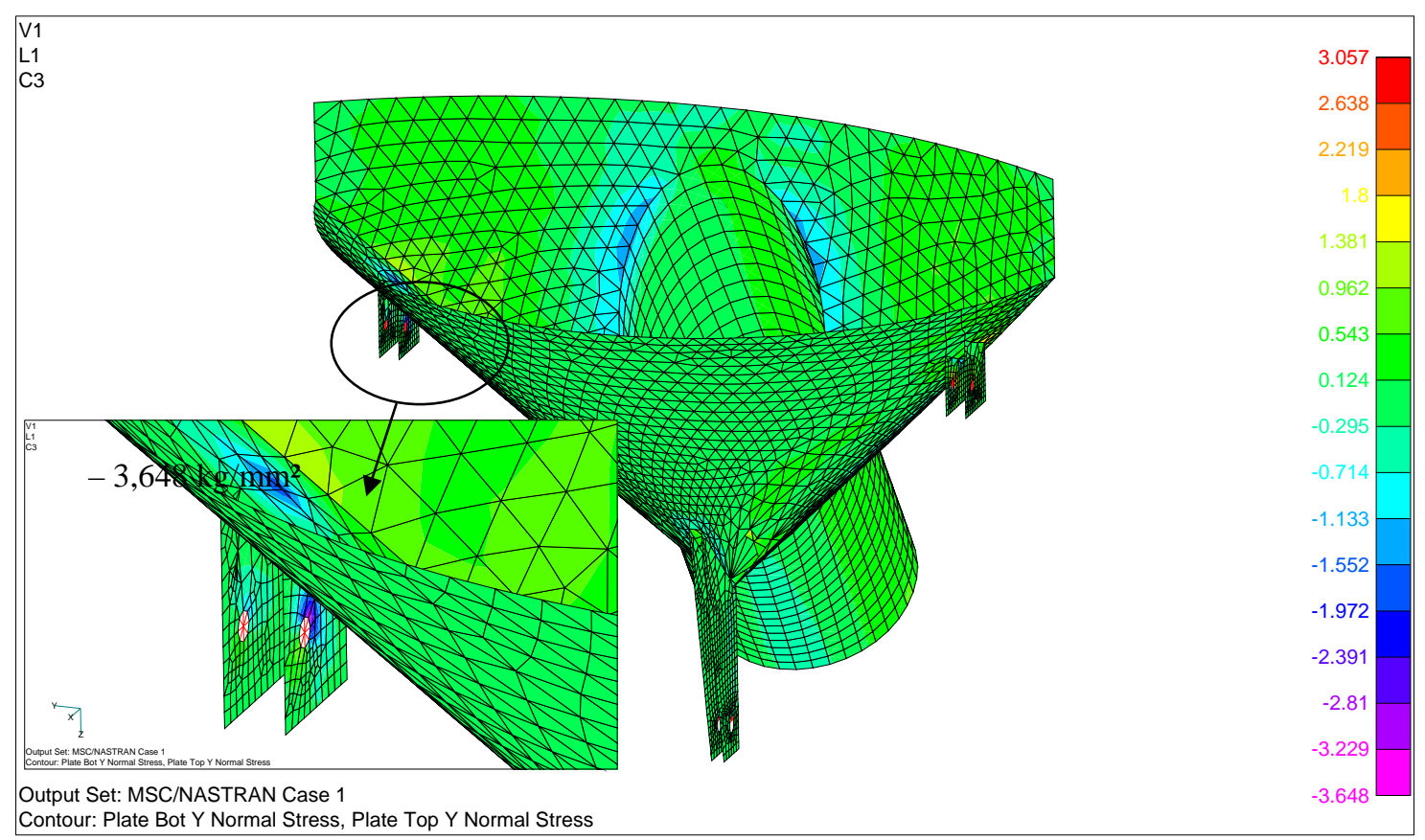

Gambar 3.

Distribusi Tegangan Pada Hopper Akibat Pressure Flow, Tegangan Pada Daerah Pin - 3,648 kg/mm²

Hasil perhitungan untuk kedua pembebanan di atas menunjukkan bahwa tegangan yang terjadi di shell hopper kecil sekitar $1 \mathrm{~kg} / \mathrm{mm}^{2}$, sedangkan tegangan yang paling besar terjadi di daerah pelat untuk pin (Gambar 2 dan 3).
Hasil perhitungan juga menunjukkan adanya momen bending pada kedua pin sebelah atas (Pin A dan B pada Gambar 1), sedangkan pada pin bawah gaya yang bekerja dominan tekan. Gaya-gaya tersebut dapat dilihat pada Tabel berikut :

Tabel 1.

Gaya yang Bekerja Pada Pin dan kg

\begin{tabular}{lllllll}
\hline Pin & Fx1 & Fx2 & Fy1 & Fy2 & Fz1 & Fz2 \\
\hline A & -379 & 752 & -232 & -855 & -380 & 1303 \\
B & 754 & -382 & 856 & 234 & 1315 & -382 \\
C & -358 & -386 & - & - & 3370 & 3625 \\
\hline
\end{tabular}

Catatan : tanda $+/$ - menunjukkan arah gaya. 


\section{FEA Pin}

Dengan menggunakan element type solid (volume element), Pin dimodelkan sebagai berikut :

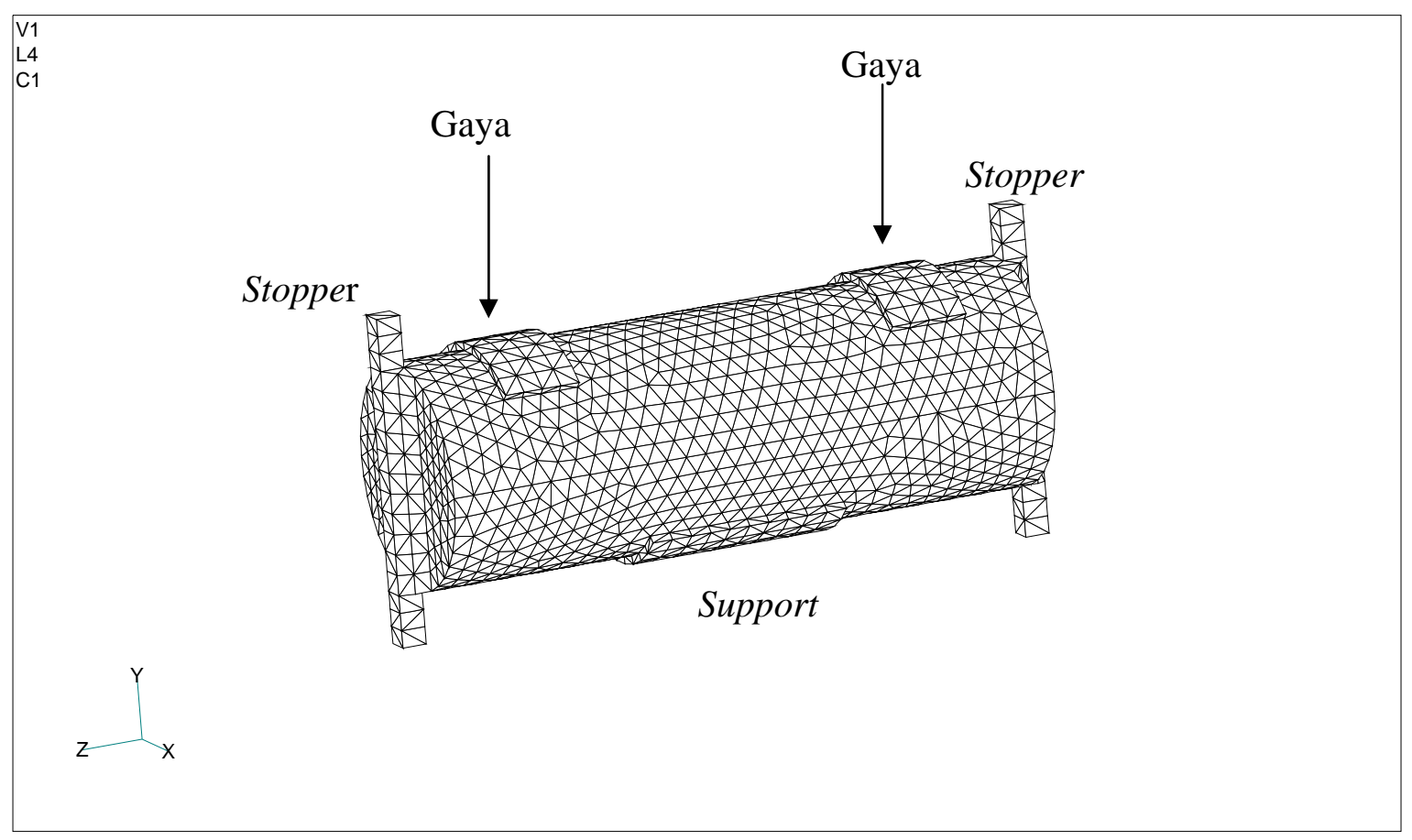

Gambar 4.

Model FEA pin

Gaya yang bekerja pada pin diambil dari hasil perhitungan hopper (Tabel 1) di atas, gaya kearah lateral (samping diterima oleh stopper). Perhitungan dilakukan pada beberapa model pin dengan diameter yang berbeda mulai dari $55 \mathrm{~mm}$ sampai dengan 75 mm.(gambar 4-9)

\section{Hasil Perhitungan}

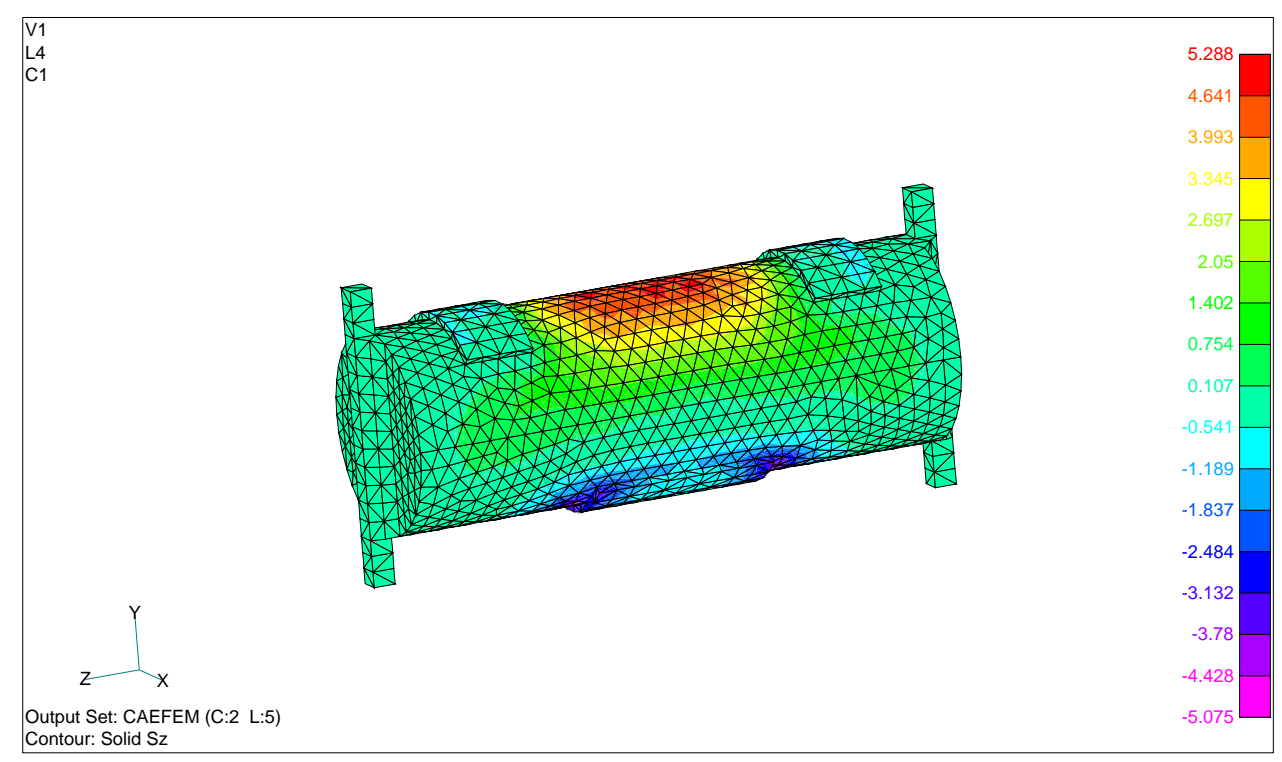

Gambar 5.

Distribusi Tegangan Pada Pin Diameter $55 \mathrm{~mm}$

Tegangan Maksimal Terjadi Pada Punggung Pin Sebesar 5,288 kg/mm² 


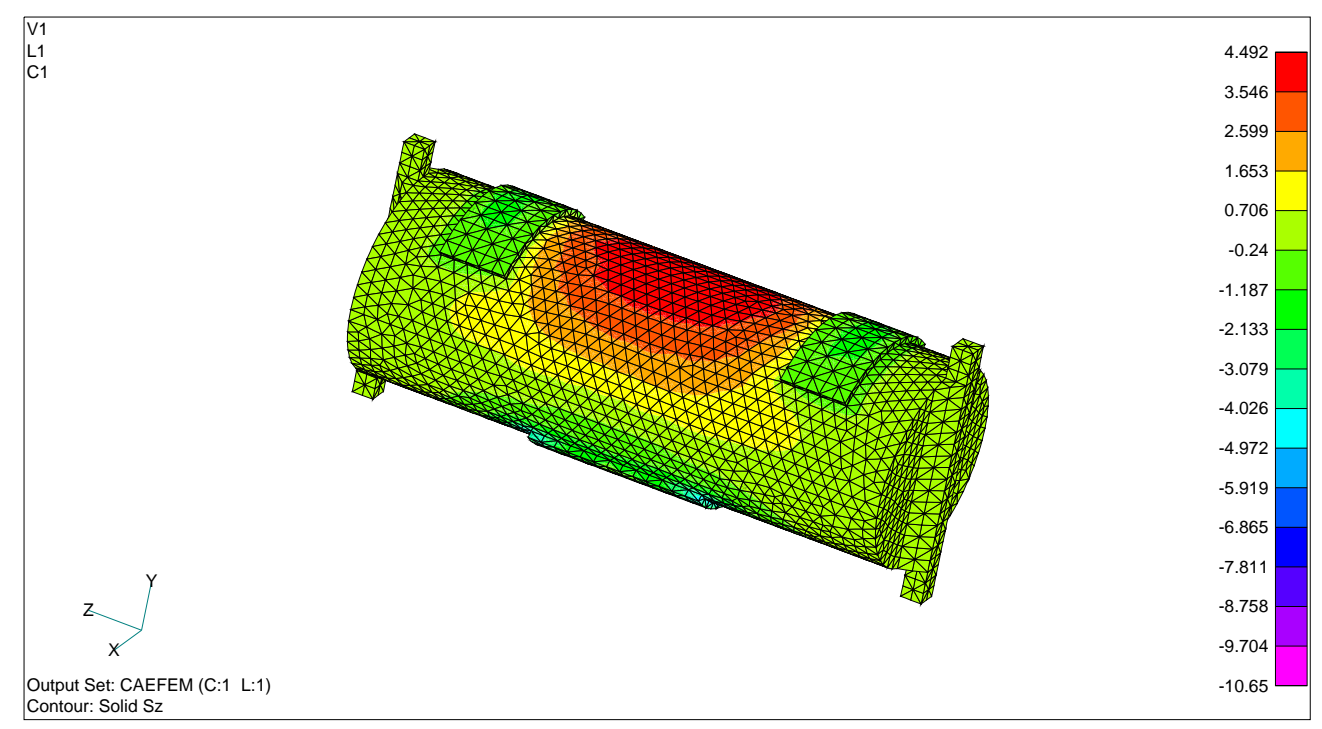

Gambar 6.

Distribusi Tegangan Pada Pin Diameter $60 \mathrm{~mm}$,

Tegangan Maksimal Terjadi Pada Punggung Pin Sebesar 4,492 kg/mm²

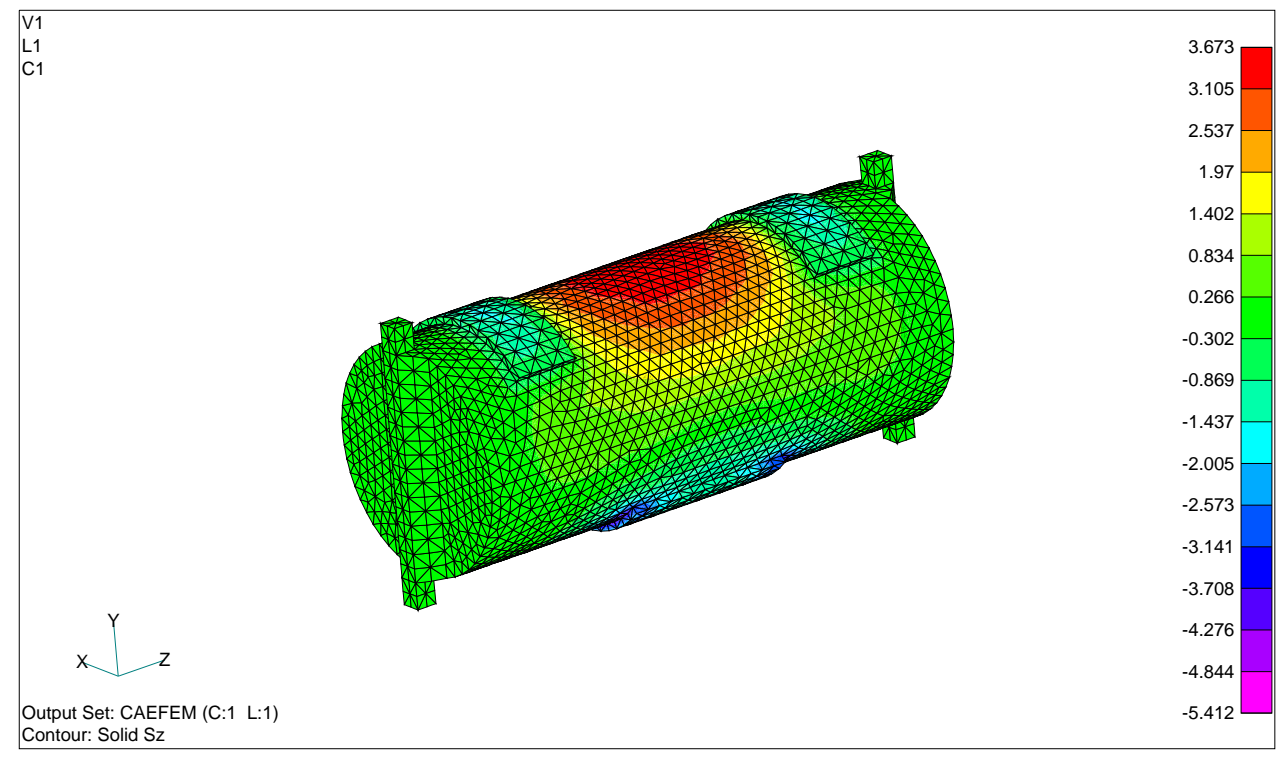

Gambar 7.

Distribusi Tegangan Pada Pin Diameter $65 \mathrm{~mm}$, Tegangan Maksimal Terjadi Pada Punggung Pin Sebesar 3,673 kg/mm² 


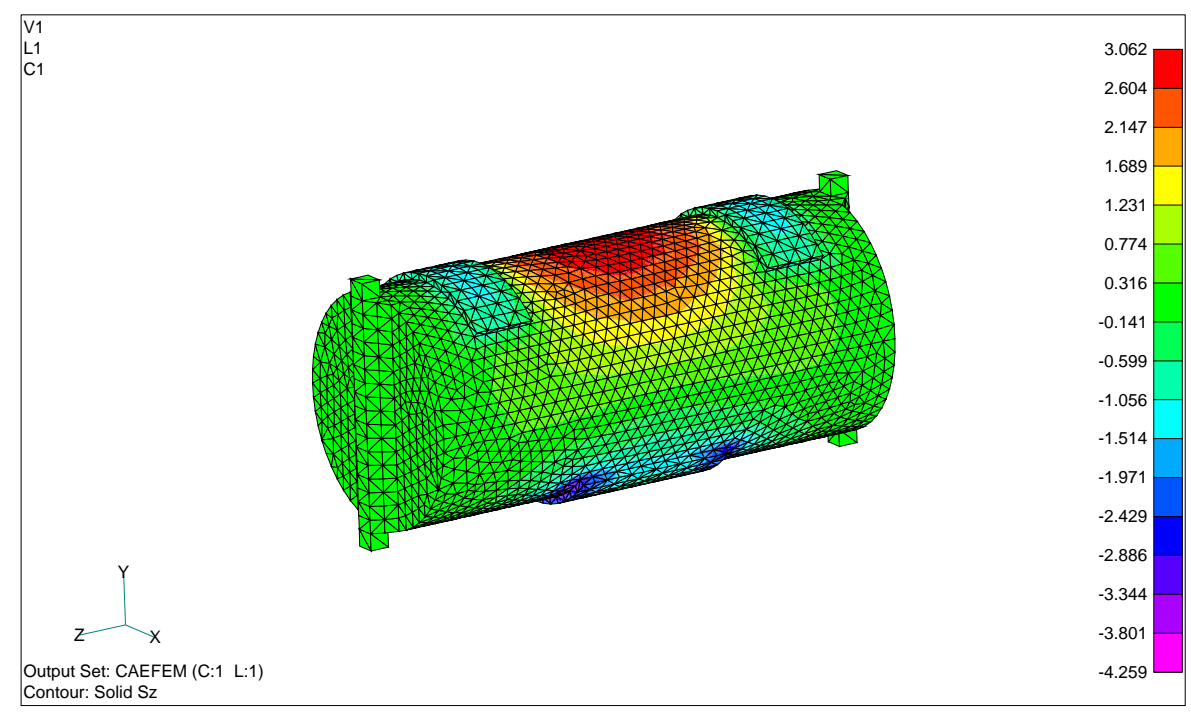

Gambar 8.

Distribusi Tegangan Pada Pin Diameter $70 \mathrm{~mm}$,

Tegangan Maksimal Terjadi Pada Punggung Pin Sebesar 3,062 kg/mm²

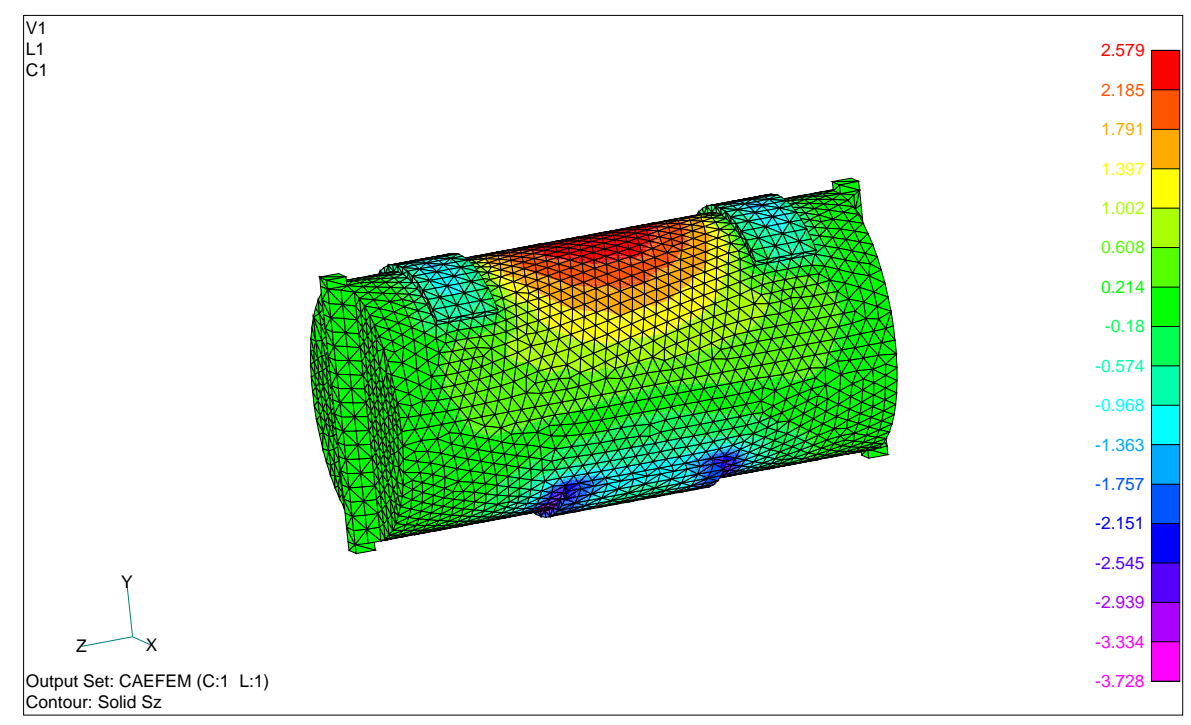

Gambar 9.

Distribusi Tegangan Pada Pin Diameter $75 \mathrm{~mm}$

Tegangan Maksimal Terjadi Pada Punggung Pin Sebesar 2,579 kg/mm²

Dari perhitungan stress analysis gambargambar diatas dilakukan secara bertahap mulai dengan pin diameter $55 \mathrm{~mm}$ sampai dengan pin berdiameter $75 \mathrm{~mm}$, secara detail adalah sebagai berikut: pada (gambar.5) dengan pin diameter $55 \mathrm{~mm}$ tegangan maximal yang terjadi pada punggung pin sebesar $5,288 \mathrm{~kg} / \mathrm{mm}^{2}$ (pada titik merah paling atas), dan berikutnya dilakukan stress analysis (gambar 6) dengan mengganti pin dengan diameter yang lebih besar yaitu $60 \mathrm{~mm}$, ternyata diperoleh hasil tegangan maximal menjadi berkurang menjadi $4,492 \mathrm{~kg} / \mathrm{mm}^{2}$, tegangan ini masih melebihi tegangan maximal yang diizinkan yaitu $3.36 \mathrm{~kg} / \mathrm{mm}^{2}$. Perhitungan dilanjutkan dengan mengganti diameter pin menjadi 65 $\mathrm{mm}$ dan hasil perhitungan diperoleh tegangan $3.673 \mathrm{~kg} / \mathrm{mm}^{2}$ dan seterusnya dengan pin $70 \mathrm{~mm}$ dengan hasil tegangan $3.062 \mathrm{~kg} / \mathrm{mm}^{2}$, pada kondisi dengan diameter ini sebetulnya sudah didapat hasil dengan tegangan dibawah $3.36 \mathrm{~kg} / \mathrm{mm}^{2}$, dilakukan perhitungan dengan diameter yang lebih besar yaitu $75 \mathrm{~mm}$ untuk mengetahui tegangan yang didapat, dengan hasil tegangan $2.579 \mathrm{~kg} / \mathrm{mm}^{2}$. 
Hasil perhitungan analisa tegangan fungsi diameter pin dapat dilihat pada Tabel 2 berikut:

Tabel 2.

Tegangan Maksimum \& Diameter Pin

\begin{tabular}{llllll}
\hline Diameter pin $(\mathrm{mm})$ & 55 & 60 & 65 & 70 & 75 \\
Tegangan Maks. $\left(\mathrm{kg} / \mathrm{mm}^{2}\right)$ & 5,288 & 4,492 & 3,673 & 3,062 & 2,579 \\
\hline
\end{tabular}

Dari hasil perhitungan tegangan pada pin yang dilakukan dengan diameter yang berbeda, hubungannya pun dengan tegangan pin yang dihasilkan dapat diamati secara bertahap, dengan bertambahnya besar dari diameter pin yang digunakan, maka tegangan yang terjadi semakin kecil. Demikian dilakukan seterusnya sehingga didapatkan tegangan yang optimal yang dapat memikul beban yang merupakan beban bending yang tidak boleh melebihi $3,36 \mathrm{~kg} / \mathrm{mm}^{2}$

\section{SIMPULAN}

Rupture allowable stress, Sr, untuk 100.000 jam operasi pada temperatur $750 \mathrm{C}$ adalah sebesar $3,2 \mathrm{ksi}\left(2,24 \mathrm{~kg} / \mathrm{mm}^{2}\right)$. Karena tegangan yang terjadi pada pin disebabkan oleh bending maka tegangan yang terjadi harus lebih kecil dari $1,5 \mathrm{Sr}=3,36 \mathrm{~kg} / \mathrm{mm}^{2}$, jadi sebaiknya dipakai Pin dengan diameter $70 \mathrm{~mm}$.

\section{UCAPAN TERIMA KASIH}

Penulis mengucapkan terimakasih yang sebesar-besarnya kepada rekan-rekan di Analisa Tegangan - B2TKS BPPT terutama Bapak Budi Tedjolukito, DEA dalm team yang banyak membantu akan terseleseikannya tulisan ini.

\section{DAFTAR PUSTAKA}

1. ASM Handbook Volume - 9 Thn 1998 , Metallography and Microstructures.

2. Daryl L.Logan, A first course in the finite element method, PWS-Kent Publishing Company - Boston.

3. William weaver Jr, Paul R Johnston Elemen hingga untuk analisa struktur, PT. Eresco Bandung 1989.

4. Annual book of ASTM standard.

5. Gordon W. Powel and Salah E. Mahmoud, 1998. "Failure Analysis and Prevention".

6. Vince Adams and Abraham Askenjazi, "Building Better Products With Finite Element Analysis".

7. Kong Yong Lee, Hideaki Takahashi" Fracture and Strength 90 " 